\title{
血漿蛋白質の鉄結合能の検討
}

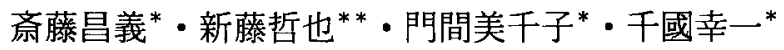

\section{Iron Binding Capacity of Plasma Proteins}

\author{
Masayoshi Saito ${ }^{*}$, Tetsuya ShindoH $^{* *}$, Michiko Monma ${ }^{*}$ \\ and Koichi CHIKuni* \\ * National Food Research Institute, Ministry of Agriculture, Forestry \\ and Fisheries, 2-1-2 Kannondai, Tsukuba-shi, Ibaraki 305 \\ ** Tokyo Metropolitan Food Technology Research Center, \\ 1-9 Kandasakuma-cho, Chiyoda-ku, Tokyo 101
}

\begin{abstract}
Iron binding capacity of plasma proteins from slaughtered pig were investigated with a view to using them as iron binding materials in food processing. Iron content of samples (SI) and unsaturated iron binding capacity (UIBC) were measured according to NitrosoPSAP method. Total iron binding capacity (TIBC) and saturation percentage (S\%) were calculated from following equations; $\operatorname{TIBC}(\mu \mathrm{g} \cdot \mathrm{Fe} / \mathrm{g})=\mathrm{UIBC}+\mathrm{SI}, \mathrm{S} \%=(\mathrm{SI} / \mathrm{TIBC}) * 100$. TIBC of plasma proteins was higher than that of whey powder, but lower than that of egg white powder. Iron saturation percentage of plasma proteins was about $50 \%$, which was higher than that of whey or egg white powder. It was possible to obtain a fraction having high iron binding capacity from plasma proteins by ion-exchange chromatography. Iron binding capacity was stable in neutral or alkaline $\mathrm{pH}$ region during storage of plasma protein solution at $4^{\circ} \mathrm{C}$. On the other hand, iron binding capacity was stable in acidic $\mathrm{pH}$ region during heat treatment of plasma protein solution at $80^{\circ} \mathrm{C}$. Iron binding capacity decreased remarkably with peptic hydrolysis of plasma proteins. We concluded that it is possible to develop food materials having iron binding capacity from plasma proteins.
\end{abstract}

(Received Dec. 8, 1992)

屠殺した牛，豚から採血し，これを食品素材として利 用するための研究が進められている. 血慜蛋白質の利用 を進めるに当たっては，血漿蛋白質の持つ優れた特性， または血嶈蛋白質にしか認められない特性を食品素材と して活用することによって，付加価值を高めることが可 能である。ここで我々は，血漿蛋白質の乳化特性 ${ }^{1)}, フ ゚$ ロテアーゼ阻害活性 ${ }^{2)}$ などを解明し，特性を活用した食 品素材への利用方法について検討してきた。

血漿中にはトランスフェリンが存在して、これが鉄を 結合し，運搬している3゙，乳清に含まれるラクトフェリ ン4)，卵白に含まれるオボトランスフェリン5などと共
に, トランスフェリンの持つ鉄結合能は, 生化学的な見 地から解明か淮められている. しかし, 乳清, 卵白につ いては，食品として利用する見地加らも鉄結合能の解明 が進められているのに対し，血將蛋白質に関しては，食 品素材として鉄結合能を利用するための研究はほとんど なされていない.

鉄の供給源となる食品や飲料が，貣血を防止する観点 などから注目されている現在，血漿蛋白質の持つ鉄結合 能の利用も進めら饥るべきであろう、本研究では，血墏 蛋白質を鉄の供給源となる食品素材として利用すること を目的として，血漿蛋白質の鉄結合能を検討した。

* 農林水産省食品総合研究所（干305 茨城県っくば市観音台 2-1-2）

** 東京都立食品技術センター（厂101 東京都千代田区神田佐久間町 1-9） 


\section{実 験 方 法}

1. 材 料

（1）血漿蛋白質の調製

血漿蛋白質は，前報 ${ }^{1}$ と同様に豚血液から調製し，凍 結乾燥したものを試料とした.

（2）その他の蛋白質

アポートランスフェリン（Sigma 社，T-5761），牛血 漿粉 (American Protein 社)，ホエー粉（サンラク $\mathrm{N}$ ，太陽化学）および卵白粉 (太陽化学) を使用した。

\section{2. 鉄結合能の測定}

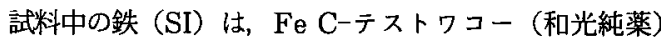
を使用して, Nitroso-PSAP 直接法で測定した。試料 に界面活性剤抢よび還元剤（チオグリコール酸）を含む 緩衝液を加え，蛋白質と結合している鉄を遊離させた。 遊離した鉄のうち， $\mathrm{Fe}^{3+}$ を還元剤で $\mathrm{Fe}^{2+}$ に還元し， これに，2-ニトロソ-5-（N-プロピル-N-スルホプロピ ルアミノ）フェノール（Nitroso-PSAP）を結合させ て $750 \mathrm{~nm}$ に吸収極大を持つキレート化合物を生成さ世 た.この吸光度を測定して試料中の鉄濃度を求めた。

不飽和鉄結合能 (UIBC) は，UIBC-テストワコー （和光純薬）を使用して測定した。試料に還元剤（メ夕 重严硫酸ナトリウム) と既知過剩量の鉄（105 $\mu \mathrm{g}$ ・ $\mathrm{Fe}^{2+} / \mathrm{d} l$ ) を含む緩衝液を加え，遊離の鉄を結合する働 きのある蛋白質と緩衝液中の鉄を結合させた，その後，

Nitroso-PSAP を添加し，蛋白質と結合せずに緩衝䘸 中に残っている鉄（残余鉄）とキレート化合物を生成さ せ, この $750 \mathrm{~nm}$ の吸光度加ら残余鉄濃度を求めた。初 めの緩衝液に含まれていた既知過剩量の鉄加ら，残余鉄 を差し引くことにより，試料中の蛋白質と結合した鉄の 量（不䝭和鉄結合能）を算出した。

いずれの測定においても，試料は，1\%または $0.1 \%$ $(\mathrm{w} / \mathrm{v})$ 水溶液とし, $1 \mathrm{~m} l$ を測定に使用した. SI お上 び UIBC は試料 $1 \mathrm{~g}$ 当たりの鉄の $\mu \mathrm{g}$ 数 $(\mu \mathrm{g} \cdot \mathrm{Fe} / \mathrm{g})$ として算出した。

鉄結合能（TIBC）おょび飽和度（S\%）は，以下の 式より算出した6).

$$
\begin{aligned}
& \text { TIBC }(\mu \mathrm{g} \cdot \mathrm{Fe} / \mathrm{g})=\mathrm{UIBC}+\mathrm{SI} \\
& \mathrm{S} \%=\left(\frac{\mathrm{SI}}{\mathrm{TIBC}}\right) \times 100
\end{aligned}
$$

\section{3. 血漿蛋白質の分画}

血漿蛋白質のイオン交換クロマトグラフィーによる分 画を前報”同様に行った．5つの画分（A１加 A 5) に分画し，凍結乾燥したものを鉄結合能の測定に用いた。

\section{4. 蛋白質溶液の貯蔵}

蒸留水に，血漿蛋白質は $1 \%$ （w/v）となるように， トランスフェリンは $0.1 \%$ （w/v）となるように溶解さ せ、これらの溶液の $\mathrm{pH}$ を 3,7 または 9 に, $1 \mathrm{~N} \mathrm{HCl}$

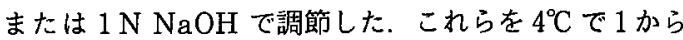
7 日間賍蔵し，その後，鉄結合能の測定に用いた。

\section{5. 蛋白質の加熱による変性}

血漿蛋白質およびトランスフェリン溶液を前項，蛋白

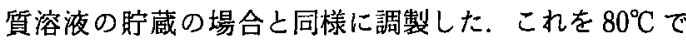
5 から 30 分間加熱処理し，その後水浴中で直ちに室温 へ戻し，鉄結合能の測定に用いた。

\section{6. 血㪇蛋白質のペプシンによる分解}

血獎蛋白質のペプシンによる分解を前報 ${ }^{8)}$ 同様に行っ た. 䣲菜/基質 $=1 / 1000(\mathrm{w} / \mathrm{w}), \mathrm{pH} 3.7,40^{\circ} \mathrm{C}$ で 20

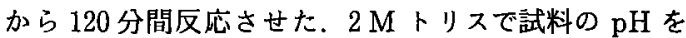
8.2 に調節して反応を停止させ，透析，凍結乾燥したも のを鉄結合能の測定に用いた。

\section{実験結果及び考察}

\section{1. 血齿蛋白質の鉄結合能}

Table 1 に蛋白質の鉄結合能 (TIBC) と飽和度 (S \%）を示した，血嶈蛋白質の鉄結合能は $65.7 \mu \mathrm{g} \cdot \mathrm{Fe} /$ gで， $50.1 \%$ が飽和されていた．市販の牛血獎粉の鉄 結合能は今回調製した試料よりも低く，飽和度は $100 \%$ で，遊離の鉄を結合する能力は全くなかった．トランス フェリンの鉄結合能は血漿蛋白質の約 15 倍であり，ア ポ型（鉄を結合していないタイプ）であったため，飽和

Table 1 Total iron binding capacity and saturation percentage of various proteins

\begin{tabular}{lcc}
\hline \hline & $\begin{array}{c}\text { TIBC } \\
(\mu \mathrm{g} \cdot \mathrm{Fe} / \mathrm{g})\end{array}$ & $\begin{array}{c}\mathrm{S} \\
(\%)\end{array}$ \\
\hline Plasma proteins* $^{*}$ & 65.7 & 50.1 \\
Plasma powder (bovine) $^{* *}$ & 48.5 & 100 \\
Egg white powder** $^{*}$ & 91.2 & 0.0 \\
Whey powder* $^{* *}$ & 21.7 & 20.7 \\
Transferrin $^{* * *}$ & 971 & 7.2 \\
\hline
\end{tabular}

TIBC: total iron binding capacity, S: saturation percentage. These are calculated from following equations, $\mathrm{TIBC}=\mathrm{UIBC}+\mathrm{SI}, \mathrm{S}(\%)=(\mathrm{SI} / \mathrm{TIBC}) *$ 100 where UIBC is unsaturated iron binding capacity and SI is iron content of samples. ${ }^{*}$ : prepared in a laboratory, ${ }^{* *}$ : food additive on the market, ${ }^{* * *}$ : powder for laboratory use. 
度は $7.2 \%$ と低い值を示した。ホエー粉の鉄結合能は血 獎蛋白質よりも低く，卵白㸮の鉄結合能は血漿蛋白質よ りも高かった，いずれの場合も飽和度は低く，畉白粉の 飽和度は $0 \%$ であった。

トランスフェリンは，分子量約 81000 の糖蛋白質で, 1 分子当たり 2 原子の $\mathrm{Fe}^{3+}$ イオン之結合することが知 られている゙．ラクトフェリン，オボトランスフェリン 上共通な1次構造部があり，鉄イオンとキレートするア ミノ酸残基として，チロシン，ヒスチジンが関与してい ると考えられている，さらに，これらの蛋白質は，鉄と 結合すると $470 \mathrm{~nm}$ 付近に吸収を持つ淡紅色を呈する ことでも共通の性質を有する ${ }^{4)}$.この様に，鉄結合能に 関しては，一般に検討されている乳清蛋白質などのかわ りに，類似した性質を持つ，血漿蛋白質を使用すること が可能と考えられる.

鉄結合能が高ければ，あらかじめ鉄を飽和させて，鉄 の供給源となる食品素材としての利用が可能である. 市 販されている鉄を含む飲料は $8 \mu \mathrm{g} \cdot \mathrm{Fe} / \mathrm{ml}$ 程度であり， この鉄濃度にするには, トランスフェリンで $0.83 \%$ ，

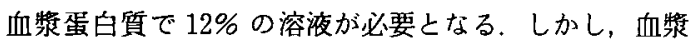
蛋白質の場合, 実際上この椂な高濃度での利用は困難で あるので，鉄結合能が高い画分を調製して利用するなど の検討が必要であろう.

乳清，卵白のように，鉄の飽和度が低い場合，遊離の 鉄を結合して微生物に利用できない状態にするため, 静 菌作用が期待できる ${ }^{4) 5}$. 血墏蛋白質の飽和度は約 50\% であることから，血墏蛋白質を静菌作用を持った食品菜 材として利用することも可能であると考えられ，今後こ の点の検討も必要であろう。

\section{2. 血獎蛋白質分画物の鉄結合能}

Table 2 に血槳蛋白質の分画物の鉄結合能抢上び飽 和度を示した. A 1, A 3，A 4 画分の鉄結合能は低く， A 2 画分に鉄結合能があることが示された．飽和度む，

A 1，A 3，A 4 画分では $100 \%$ であり遊離の鉄を結合 する能力は全くないが，A 2 画分では $37.5 \%$ と比較的 低い值であった。 なお，A 5 画分は，溶解性が低いため, 鉄結合能の測定は行わなかった。

血嶈中の鉄の $95 \%$ 以上は，トランスフェリンに結合 したものであることが知られている゙．A 2 画分は， ト ランスフェリンが主な成分であり”．A２画分の鉄結合 能が高いことは, トランスフェリンの働きによるあのと 考えられる。

このように，イォン交換クロマトグラフィーによる分 画によって，鉄結合能の高い素材を調製することが可能
Table 2 Total iron binding capacity and saturation percentage of fractionated plasma proteins

\begin{tabular}{lcc}
\hline \hline & $\begin{array}{c}\text { TIBC } \\
(\mu \mathrm{g} \cdot \mathrm{Fe} / \mathrm{g})\end{array}$ & $\begin{array}{c}\mathrm{S} \\
(\%)\end{array}$ \\
\hline Whole plasma & 65.7 & 50.1 \\
Fraction A 1 & 6.1 & 100 \\
Fraction A 2 & 305.9 & 37.5 \\
Fraction A 3 & 23.3 & 100 \\
Fraction A 4 & 17.3 & 100 \\
Fraction A 5 & - & - \\
\hline
\end{tabular}

TIBC and $\mathrm{S}(\%)$ are the same as in Table 1.

Fractionated by ion-exchange chromatography. - : not measured because of the precipitation.

であった．他の画分のうち，A１は $\gamma$-グロブリン，A 3 はプロテアーゼ阻害蛋白質，A４は血清アルブミンに富 むことが示されている277. A 2 画分に対しては鉄結合 能を活用した利用方法を検討し，A２以外の画分はそれ ぞれの蛋白質の特性を活用した利用方法を考えることで， 血嶈蛋白質全体としての利用性の向上が計られるである j.

\section{4. 鉄結合能の安定性}

Fig. 1 に $1 \%$ 血漿蛋白質溶液を $4^{\circ} \mathrm{C}, \mathrm{pH} 3,7$ また は 9 において眝蔵したときの鉄結合能および鴭和度の変 化を示した．血浆蛋白質溶液を $\mathrm{pH} 3$ で眝蔵した場合 では, 鉄結合能は経過日数之共に低下し，7日後は初め の約 $40 \%$ となった．このとき飽和度は上昇し，4 日目 から $100 \%$ となった，pH 7, 9 で保存した場合，鉄結 合能, 飽和度共に変化はわずかであった。

Fig. 2 に $0.1 \%$ トランスフェリン溶液を $4^{\circ} \mathrm{C}, \mathrm{pH}$ 3，7または 9 において貯蔵したときの鉄結合能および 飽和度の变化を示した。トランスフェリンの場合は， $\mathrm{pH} 3 ， 7 ， 9$ ともに，鉄結合能，飽和度の変化はわずか であった.

今回の結果からは，血嶈蛋白質はトランスフェリンと 比較して，酸性領域において眝蔵した場合に鉄結合能が 低下しやすいことが示された：また，いずれの場合も， $\mathrm{pH} 3$ では初めから他の $\mathrm{pH}$ より鉄結合能が低い値とな っていた.

Fig. 3 に $1 \%$ 血漿蛋白質溶液の加熱処理による鉄結

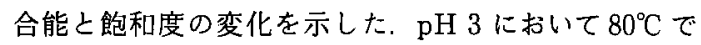
加熱しても鉄結合能, 飽和度ともに变化はわずかであっ たが, $\mathrm{pH} \mathrm{7,9}$ における加熱で, 30 分後に鉄結合能は 


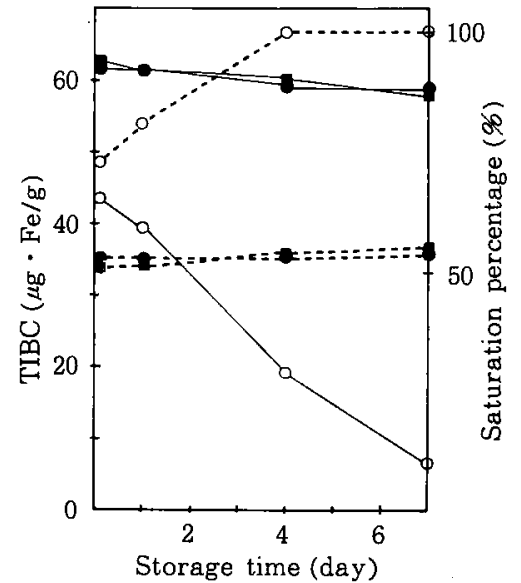

Fig. 1 Changes in total iron binding capacity (TIBC) and saturation percentage (S\%) of plasma proteins during storage at $4^{\circ} \mathrm{C}$ under various $\mathrm{pH}$ conditions

- : total iron binding capacity, ---- : saturation percentage

$\mathrm{O}: \mathrm{pH} 3, \bullet: \mathrm{pH} 7, \boldsymbol{\square}: \mathrm{pH} 9$.

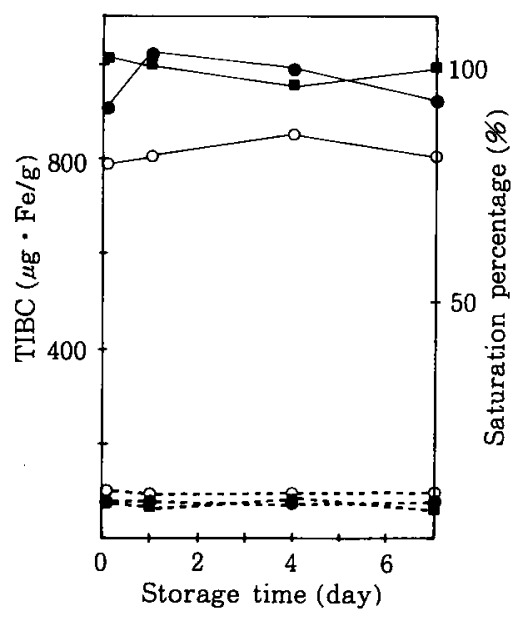

Fig. 2 Changes in total iron binding capacity (TIBC) and saturation percentage $(\mathrm{S} \%)$ of transferrin during storage at $4^{\circ} \mathrm{C}$ under various $\mathrm{pH}$ conditions

Symbols are the same as in Fig. 1

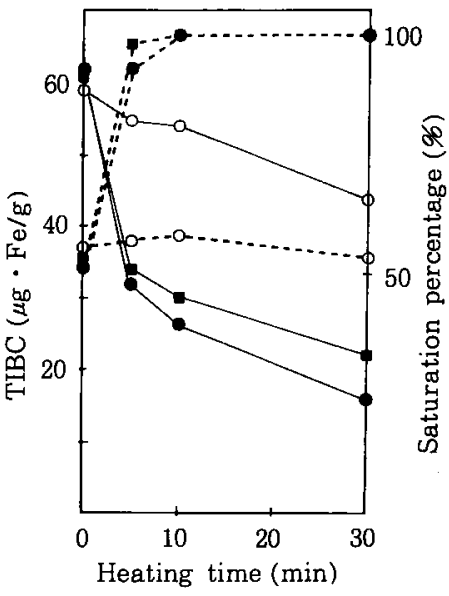

Fig. 3 Changes in total iron binding capacity (TIBC) and saturation percen. tage $(\mathrm{S} \%)$ of plasma proteins during heat treatment at $80^{\circ} \mathrm{C}$ under various $\mathrm{pH}$ conditions

Symbols are the same as in Fig. 1

加熱前の 30\% 以下まで低下した．飽和度も10 分後には $100 \%$ となった。

Fig. 4 に $0.1 \%$ トランスフェリン溶液の加熱処理に よる鉄結合能と飽和度の变化を示した. $\mathrm{pH} 9$ において 鉄結合能の低下が著しく，30 分後には加熱前の $10 \%$ 以 下となり，盷和度る $100 \%$ となった。 $\mathrm{pH} 3$ においては

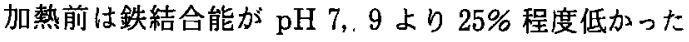
が，加熱による低下は他の $\mathrm{pH}$ と比較してわずかであ った.

食品加工においては，殺菌の目的等で血漿蛋白質を加 熱処理することが多い，今回の結果からは， $80^{\circ} \mathrm{C} 30$ 分 間の加熱処理を行う場合，中性またはアルカリ性領域で は血嶈蛋白質の鉄結合能が著しく低下するのに対し，酸 性領域では血漿蛋白質の鉄結合能があまり低下しないこ とが示された。

また，血漿蛋白質とトランスフェリンには，酸性溶液 で眝蔵した場合や中性溶液で加熱した場合の鉄結合能の 変化に異なった傾向がみられた。これは，血等蛋白質は 多くの種類の蛋白質の混合物であるため，異種の蛋白質 の相互作用が変性に影響を及ぼしていることが原因と考 えられる．また，血漿蛋白質とトランスフェリンでは処 理前の飽和度に差があったが，この影響も考えられる。 今後は，同一試料で飽和度が異なる場合の鉄結合能の安 


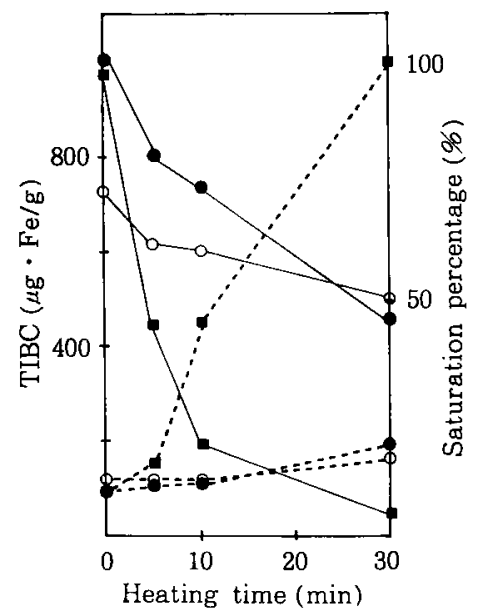

Fig. 4 Changes in total iron binding capacity (TIBC) and saturation percentage $(\mathrm{S} \%)$ of transferrin during heat treatment at $80^{\circ} \mathrm{C}$ under various $\mathrm{pH}$ conditions

Symbols are the same as in Fig. 1

定性も検討する必要があると思われる.

血漿蛋白質溶液を低温で眝蔵する場合，中性，または アルカリ性領域の方が鉄結合能が安定であるのに対し， 血獎蛋白質溶液を加熱処理する場合には，酸性領域で行 った方が安定であった．このように，鉄結合能の安定な 条件は，溶液を眝蔵するのか，加熱するのかで全く異な っていることが示された.

\section{4. 血㱩蛋白質のペプシン分解物の鉄結合能}

Fig. 5 に血筝蛋白質のペプシン分解による鉄結合能 と飽和度の変化を示した. 血漿蛋白質の 20 分間分解物 は，分解前の鉄結合能の $15 \%$ 程度まで低下しており， 40 分間以上分解した場合は，ほとんど鉄結合能が失わ れた．飽和度す 20 分間の分解で $100 \%$ となった。

前報 ${ }^{8)}$ において示されたように，血墏蛋白質をぺプシ ンで 20 分間加水分解した場合，蛋白質のほとんどが分 子量 25000 以下に分解されていた。このような分解物 では鉄結合能はほとんど残っておらず，鉄を結合するた めには分解されていない蛋白質の構造が必要であること が示された。

一方，血蒋蛋白質分解物のトリプシンに対する阻害活 性を測定した結果は，120 分分解物であ50\%以上の活 性が残っていた ${ }^{2}$. 血獎蛋白質の分解で，鉄結合能のよ うに容易に失われる性質と, トリプシン阻害活性のよう

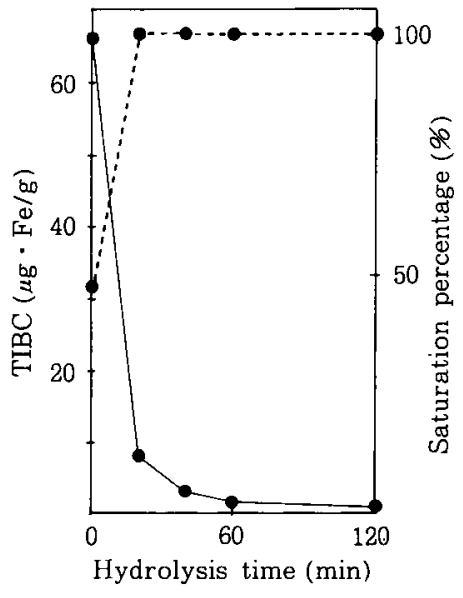

Fig. 5 Changes in total iron binding capacity (TIBC) and saturation percentage $(\mathrm{S} \%)$ of plasma proteins during peptic hydrolysis

- : total iron binding capacity, -.- : saturation percentage

に比較的失われにくい性質があることが明かとなった。

以上のことを通して，血漿蛋白質の鉄結合能を利用し て，これを鉄の供給源となる食品素材として利用するこ とが可能であり，この時 $\mathrm{pH}$ 等の条件設定が重要であ ることが示された。 また，飽和度の低い場合は，静菌作 用を持った食品素材としての利用が可能であり，この点 については今後さらに検討する必要があると考えている.

要 約

1. 血獎蛋白質の鉄結合能はホエー粉より高く，卵白 粉より低い値を示した．血墏蛋白質の鉄結合能を食品素 材として利用することが可能と考えられた。また，市販 の血獎粉は実験室規模で調製した血漿蛋白質より鉄結合 能が低い值であった。

2. 血漿蛋白質をイオン交換クロマトグラフィーで分 画すると,トランスフェリンを含む画行の鉄結合能が高 く，飽和度は低い值を示した.この画分が鉄結合能を活 用した利用に適していることが示された。

3. 血漿蛋白質溶液を眝蔵した場合，鉄結合能は中性， アルカリ性領域で安定であった，一方，血漿蛋白質溶液 を加熱処理した場合，鉄結合能は酸性領域の方が安定で あった.

4. 血獎蛋白質をペプシンで加水分解すると，鉄結合 
能は容易に低下した。

豚血液の採取に当たってお世話頂いた，農林水産省畜 産試験場 中井博康室長に感謝いたします。

\section{文献}

1）斎藤昌義・石橋恵美子・平 春枝：日食工誌， 37 , $805(1990)$

2）闵藤昌義・門間美千子・千國幸一：日食工誌，39, 901 (1992).

3）吉野芳夫・折茂英生・久安早苗・神成節子・平井
幸彦: 続生化学実験講座 8 血液（上），日本生化 学会編（東京化学同人，東京）, p. 461 (1987)。

4）山内邦男：農化，53， R 37 (1979).

5）佐藤 泰：食卵の科学之利用, (地球社, 東京), p. 55 (1980).

6）村井哲夫：臨床化学検查（II）, 石井 暢編，(医 学書院，東京), p. 296 (1975).

7) Saito, M. IchiKawa, N. and Taira, H. : Agric. Biol. Chem., 52, 2831 (1988).

8）斎藤昌義・平 春枝・清水 誠・山内邦男：日食 工誌, 38, 920 (1991).

(平成 4 年 12 月 8 日受理) 